\title{
LIFE PERSPECTIVES AS FACTORS OF PSYCHOLOGICAL WELL-BEING OF PERSONALITY
}

In Happiness And Contemporary Society : Conference Proceedings Volume (Lviv, March, 20-21, 2021). Lviv: SPOLOM, 2021. P. 275-276. https://doi.org/10.31108/7.2021.61

ISBN 978-966-919-697-2

ВОЛОДАРСЬКА Наталія

\section{ЖИТТЕВІ ПЕРСПЕКТИВИ \\ ЯК ЧИННИКИ ПСИХОЛОГІЧНОГО БЛАГОПОЛУЧЧЯ ОСОБИСТОСТІ}

// Щастя та сучасне суспільство : збірник матеріалів міжнародної наукової конференції (Львів, 20-21 березня 2021 р.). - Львів : СПОЛОМ, 2021. С. 275-276. https://doi.org/10.31108/7.2021.61

ISBN 978-966-919-697-2 
https://doi.org/10.31108/7.2021.61

VOLODARSKA Nataliia

PhD in Psychology, Senior Researcher

G.S.Kostyuk Institute of Psychology of the National Academy of Sciences of Ukraine (Kyiv, Ukraine)

\section{LIFE PERSPECTIVES AS FACTORS OF PSYCHOLOGICAL WELL-BEING OF PERSONALITY}

The article considers the phenomenon of psychological well-being through the features of life prospects formation and strategies for achieving them. Various research approaches are identified to the phenomenon of psychological well-being, which may occur through peculiarities of the personality's future structuring. Many studies of the problem of psychological well-being consider this phenomenon as close but not identical to the concept of happiness, optimism and life satisfaction. The above phenomena contain a positive assessment of own life, which is the basis for a sense of subjective well-being formation. The issues are analyzed of differentiation and separation of factors that determine the state of subjective well-being, their systematization and features of influence. The age features of psychological well-being are singled out. Particular attention is paid to the influence of value orientations. They are considered as components of life prospects that form the psychological well-being.

\section{ВОЛОДАРСЬКА Наталія}

кандидат психологічних наук, старший науковий співробітник

Інститут психологї̈ імені Г.С.Костюка НАП України(м. Київ, Україна)

\section{ЖИТТСВІ ПЕРСПЕКТИВИ ЯК ЧИННИКИ ПСИХОЛОГІЧНОГО БЛАГОПОЛУЧЧЯ ОСОБИСТОСТІ}

Щастя, як феномен психологічного стану людини простежується протягом усього життя. Цей стан впливає на формування життєвих цілей, планів на майбутнє. Цей стан охоплює усю психічну сферу людини й простежується у особливостях форм поведінки, цілеспрямованій діяльності на досягнення почуття психологічного благополуччя. Життєва перспектива - це цілісна картина майбутнього, яка формується у складному суперечливому взаємозв'язку очікуваних і планованих подій, розглядається в єдності ціннісно-смислових й організаційно-діяльнісних аспектів, де істотними $\epsilon$ активність особистості, усвідомлене та реалістичне ставлення до побудови планів на майбутнє. Тому, на наш погляд, необхідно розглядати життєві перспективи особистості у тісному зв'язку з життєвими стратегіями їх досягнення. Оскільки життєві перспективи формують майбутнє особистості, іiі діяльність, досягнення психологічного комфорту, то це впливає на потенційну можливість розвитку особистості. Особистість вибудовує таким чином свої плани дій, щоб отримати задоволення, впевненість у дієвості своїх розрахунків. Вона використовує життєвий досвід минулих досягнень власного життя та чужого,аналізуючи реалістичність життєвих стратегій та перспектив. 
Визначаючи поняття психологічного майбутнього, пропонуємо розрізняти психологічну, особистісну та життєву перспективи як три різних явища. Психологічна перспектива - здатність уявно та свідомо передбачати й прогнозувати майбутнє, залежить від типу особистості. Особистісна - розуміється як готовність до майбутнього в теперішньому, є показником зрілості особистості, потенціалу іiі розвитку та сформованості здатності до організації часу життя. Життєва - включає обставини й умови життя, що створюють для особистості за інших рівних умов можливість оптимального життєвого просування, i відкриваєтьсятому, хто має життєву позицію, що цілісно визначає майбутнє особистості. Пов'язуючи поняття життєвої перспективи 3 концепцією життєвого шляху особистості, ми визначаємо іiі як потенціал, можливості особистості, що об'єктивно складаються в теперішньому часі, і які повинні проявлятися в майбутньому. Життєва перспектива, будучи елементом суб'єктивної картини життєвого шляху особистості, є складною ієрархічною системою, що регулює начало життєдіяльності, й структурними одиницями якої вважають ціннісні орієнтації, життєві цілі, програми, плани, а також емоційну, когнітивну й поведінкову складові. Дослідження феномена психологічного благополуччя може відбуватись через особливості структурування майбутнього особистості, іiі перспективи та стратегії їх досягнення. Багато досліджень проблеми психологічного благополуччя розглядають цей феномен як близький але не тотожній поняттю щастя, оптимізму, вдоволення життям. Перелічені феномени включають позитивну оцінку свого життя. Невизначеним залишається питання розмежування i виокремлення факторів, визначаючих стан суб'єктивного психологічного благополуччя, їх систематизація і особливості впливу.

Віковий аспект переживання суб'єктивного благополуччя розглядається у питаннях етапів становлення самосвідомості, ціннісно-мотиваційної сфери, що впливає на формування життєвих стратегій, проектів. Стабілізація життєвих перспектив, ролі, місця і механізмів особистісних устремлінь відбувається у віці від 20 до 30 років. Досліджуючи 120 студентів (університету імені Тараса Шевченка, 2020 р.), нами були визначені особливості їх психологічного благополуччя. Розходження між власними цінностями та цінностями інших, суспільних сприймається особистістю як дискомфорт, який знімається: 1) психологічним захистом (раціоналізація, проекція, прихована агресія та інші); 2) усвідомленням причин та самовдосконаленням. Образи майбутнього можуть трансформуватися: 1) теоретично, у вигляді міркувань, 2) образно, у вигляді візуалізації, 3) під час продуктивної діяльності у процесі поведінкової стратегії.

Крізь призму своїх цінностей і перцепцію взаємодії з окремими реаліями світу формується образ благополуччя. Фрагментарні раніше деталі, які засновані на перцепції і сенситивному досвіді, здобувають чіткість, вибудовуються в логічні умовиводи або в асоціативні ланцюжки компонентів, що взаємодіючи, стають базою для побудови архетипічних категорій добра і зла, нещастя і благополуччя, прийняття - неприйняття, віри або вакуумної порожнечі. Саме вільний вибір життєвих перспектив і стратегій стає основою психологічного благополуччя особистості. В процесі вибору певних дій і вчинків особистість відкидає одні і надає перевагу іншим цінностям, за рахунок яких відбувається формування $\mathrm{i}$ оцінювання майбутніх життєвих перспектив. Образ майбутнього стає відображенням життєвої стратегії особистості. У процесі рефлексії відбувається формування життєвих смислі. 